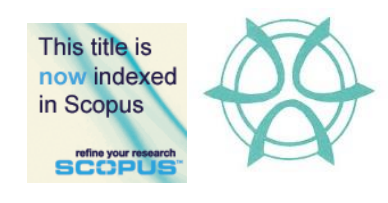

PLANNING MALAYSIA:

Journal of the Malaysian Institute of Planners

VOLUME 16 ISSUE 3 (2018) Page 57 - 68

\title{
SATISFACTION OF RESIDENTS ON THE REDEVELOPMENT OF NATURAL DISASTER AREA. CASE STUDY: KUALA KRAI, KELANTAN, MALAYSIA
}

\author{
Oliver Ling Hoon Leh ${ }^{1}$, Muhammad Shamsul Azdhar Zulkapli², \\ Kwong Qi Jie ${ }^{3}$, \& Nurul Ashikin Mabahwi ${ }^{4}$ \\ ${ }^{1,2,3}$ Faculty of Architecture, Planning and Surveying \\ UNIVERSITI TEKNOLOGI MARA, MALAYSIA \\ ${ }^{4}$ Graduate School of Engineering and Science \\ SHIBAURA INSTITUTE OF TECHNOLOGY, JAPAN
}

\begin{abstract}
Referring to the Malaysian National Security Council, disaster is defined as a catastrophic situation that claimed many lives and caused extensive damage to property and potentially endangers the public peace and security. In Malaysia, there were few natural disaster events that can be said to be among the worst ever in terms of the number of deaths and damages. However, these occurrences were not as severe as overseas. At the end of December 2014, there was a catastrophic flood called as the 'Bah Kuning' was hitting the east coast of Peninsular Malaysia. It resulted in almost $85 \%$ of the total Kuala Krai area inundated by flood water. One of the elements in post-disaster recovery is rebuilding shelter for victims. Regardless, it is important to research on residents' satisfaction as it will affect the well-being directly or indirectly. Thus, a study was carried out to evaluate the satisfaction of residents (victims) on the "New Permanent Houses" (Rumah Kekal Baharu, RKB) that they received from the redevelopment project. A questionnaire survey was carried out to collect and understand respondents' satisfaction on the redevelopment of their housing area, in specific, the quality of their newly reconstructed houses and the supporting facilities or infrastructure in their area. From the analysis, it was found that majority of the respondents were satisfied with their newly redeveloped houses and the infrastructure. The satisfaction level was associated with the locational and land ownership factors.
\end{abstract}

Keywords: disaster, flood, house, infrastructure, quality, satisfaction, security 
Oliver Ling Hoon Leh, Muhammad Shamsul Azdhar Zulkapli, Kwong Qi Jie, \& Nurul Ashikin Mabahwi

Satisfaction of Residents on The Redevelopment of Natural Disaster Area. Case Study: Kuala Krai, Kelantan, Malaysia

\section{INTRODUCTION}

At the end of December 2014, there was a catastrophic flood called as the 'Bah Kuning' hitting the east coast of Peninsular Malaysia. It resulted in almost 85\% of the Kuala Krai area, especially the Kampung Manik Urai, Kampung Manjor, Kampung Karangan, and Kampung Laloh and Dabong inundated by flood water. Due to this massive flood, residents in this Kuala Krai area have lost their properties and belonging. Loss of property, especially their shelters, clothes and vehicles, as a whole has given an impact to the residents of Kuala Krai. Manik Urai was affected the most. All residents of Manik Urai lost their homes.

After the natural disaster, there were various agencies and parties involved in the redevelopment of Kuala Krai. These include government agencies, private companies and non-governmental organisations (NGOs). Redevelopment is one of the things that is very important for an area which has suffered a natural disaster, such as massive flood. However, the issue of quality in redevelopment should not be compromised. Thus, the satisfaction of victims on the new houses and the infrastructure or facilities are crucial to be examined.

\section{LITERATURE REVIEW}

According to the National Security Council (2014), disaster is defined as a catastrophic situation that claimed many lives and caused extensive damage to property and potentially endangers the public peace and security. This often requires handling of extensive resources, equipment, frequency and manpower from many agencies as well as effective coordination, especially when complex and long-term actions are needed. Incidents of natural disasters that are included under this National Security Council's directive are floods, storms, droughts, and coastal erosion, landslides or disasters as a result of the storm and heavy rain. In addition, haze events that can cause environmental emergencies that jeopardize public order, government administration, travel and national economic activities may also be defined as a disaster. Disasters can be divided into categories such as air disaster, flood disaster, nuclear disaster, and radiology and marine disasters.

In Malaysia, there were few natural disaster events that can be said among the worst ever in terms of the number of deaths and damages. However, they were not as severe as those occurred in overseas. Malaysian geographical factors that are beyond the line of volcanoes and earthquakes also make Malaysia one of the safest nations from the threat of natural disasters. The number of natural disasters that occur in Malaysia is comparatively lesser than other countries such as countries with active volcanoes, frequent storms and so on. One of the major disaster events in Malaysia was mudflow at Post Dipang, Kampar, Perak State. The incident occurred on $29^{\text {th }}$ August 1996 in an indigenous settlement (Jasbindar, 2017). This catastrophic event was caused by logging activities that had resulted the river flow to be blocked and subsequently causing severe mud floods due to heavy rain. This incident resulted in 44 deaths while 30 
PLANNING MALAYSIA

Journal of the Malaysia Institute of Planners (2018)

houses were damaged. Another major natural disaster was the Tsunami that hit the northern coastal areas of Peninsular Malaysia, including the Penang Island and Langkawi Island ("Mengingati Tsunami 2004", 2014; Bernama, 2014). The tsunami occurred on 26 December 2004. It has shocked the whole country as Malaysian never expected to experience such disaster. The incident has caused 68 deaths in four states in Peninsular Malaysia (Penang, Kedah, Perak and Selangor). However, in Penang alone, there were 52 individuals who lost their lives. A total of 245 families had lost their homes. A total of 450 homes were damaged and repaired. This incident also caused severe damage to fishing facilities as well as affecting the income of fishermen living on the coast of Penang and Kedah.

One of the elements in post-disaster recovery is rebuilding shelter (home) for the victims. Regardless, it is important to research on residents' satisfaction of the recovery as it affects their well-being directly or indirectly. Hui and Yu (2009) in Danquah, Attippoe and Ankrah (2014), stated that residential satisfaction is a reflection of the degree to which the inhabitants feel that their housing is helping them achieve their goals.

Based on the previous study in the Philippines (Carrasco, Ochiai, \& Okazaki, 2017), residents' satisfaction with their new house after a disaster was generally associated to the appropriateness to the locality such as thermal comfort and construction quality. In general, the esidents' satisfaction with their new house after a disaster was positive. In another case, a study in Sri Lanka found that residents were satisfied with new post-disaster housing provided for the victims (Wijegunarathna, Wedawatta, Prasanna, \& Ingirige, 2018).

Viewing from the housing construction aspects, there were approximately 1,280 houses have been built through the floods' affected areas in Kelantan by the Ministry of Works (Rani, Nifa, Ismail, \& Khalid, 2017). However, as of December 2016, two years after the 2014 disastrous flood, 5\% of the victims still living in the temporary houses due to issues with land acquisition and ownership, which has delayed the construction of permanent homes by the Federal Government (Rani et al., 2017). With regard to that, it is necessary to find out residents' satisfaction of the 'New Permanent House' in Kelantan as the findings will lead to better enhancement, rapidity and robustness of community resilience.

\section{RESEARCH METHOD}

\section{Scope of Study}

This study focuses on the evaluation of satisfaction of flood victims in Kuala Krai, Kelantan of the "New Permanent Houses" (Rumah Kekal Baharu, RKB) that they received through post-flood redevelopment project. The redevelopment project was aimed to rebuild new permanent houses for the victims of the massive 
Oliver Ling Hoon Leh, Muhammad Shamsul Azdhar Zulkapli, Kwong Qi Jie, \& Nurul Ashikin Mabahwi

Satisfaction of Residents on The Redevelopment of Natural Disaster Area. Case Study: Kuala Krai, Kelantan, Malaysia

flood that occurred at the end of the year 2014. The redevelopment of housing area for the victims was carried out by the Malaysian federal government, Kelantan state government and a number of non-governmental organisations (NGOs). The satisfaction of respondents of the redeveloped housing area was studied based on the following aspects:
a) Quality of house
f) Water supply
b) Size of house
g) Electricity supply
c) Security aspect
h) Solid waste management
d) Comfort of house
i) Road condition
e) Healthy aspect of house
j) Accessibility (distance to the main road)

\section{Case Study}

At the end of December 2014, there was a catastrophic flood that was known as the 'Bah Kuning' which resulted in almost $85 \%$ of the total Kuala Krai area, especially the Manik Urai Village, Manjor Village, Karangan Village, and Laloh and Dabong Village inundated by flood water. Due to this massive flood, residents in this Kuala Krai area have lost their properties and belonging. The losses included houses, house fixtures and fittings, vehicles, and other belongings. Affected housing areas were redeveloped to provide new permanent houses for the victims. Figure 1 shows the views of the study area, Kuala Krai during the massive flood.
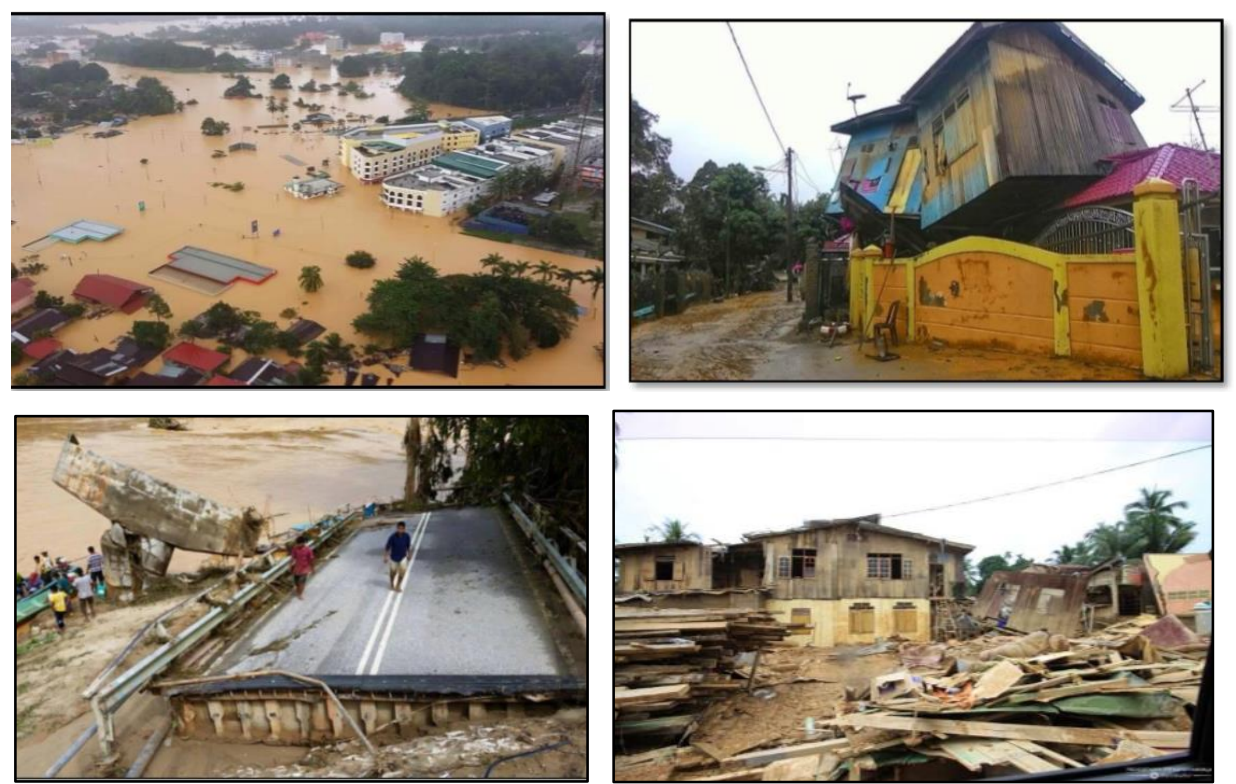

Figure 1: Views of study area when it was flooded in December 2014 


\section{Questionnaire Survey and Sampling of Respondents}

In the year 2017, a total of 896 families had received their new permanent houses (RKB) (Figure 2). Among the recipients of RKB, around 6\% (50 nos.) of them were chosen randomly as respondents for the questionnaire survey, which was carried out in the middle of 2017. The 50 respondents were given questionnaire forms to answer with the guidance from the researcher. The purpose of questionnaire survey is to collect and understand respondents' satisfaction on the redevelopment of their housing area, in specific, the quality of their newly reconstructed houses and the supporting facilities or infrastructure in their area. The samples covered both male and female, with different age groups and socioeconomic background (Table 1).

Table 1: Background of respondents

\begin{tabular}{lc}
\hline Variables & Percentage $(\%)$ \\
\hline Gender & 60 \\
Male & 40 \\
Female & \\
\hline Ethnicity & 100 \\
\hline Malay & 0 \\
\hline Age & 6 \\
\hline$<21$ years old & 26 \\
21-30 years old & 50 \\
31-40 years old & 18 \\
41-50 years old & 0 \\
$51-60$ years old & \\
$>60$ years old & 24 \\
Household income & 60 \\
< RM 1,000 & 14 \\
RM 1,000 - 1,999 & 2 \\
RM 2,000 - 2,999 & 0 \\
RM 3,000 - 4,999 & \\
$>$ RM 4,999 & 8 \\
Household size & 70 \\
\hline 1-3 members & 22 \\
$4-6$ members & \\
$>$ 6 members & \\
\hline
\end{tabular}

\section{Method of Analysis}

The data were analysed using the frequency, cross-tabulation and chi-square tests of association in the Statistical Package for Social Science (SPSS) software. The purpose of the analysis was to find out the level of satisfaction of respondents on their newly redeveloped housing area and the association to the locational and land ownership aspects. 
Oliver Ling Hoon Leh, Muhammad Shamsul Azdhar Zulkapli, Kwong Qi Jie, \& Nurul Ashikin Mabahwi
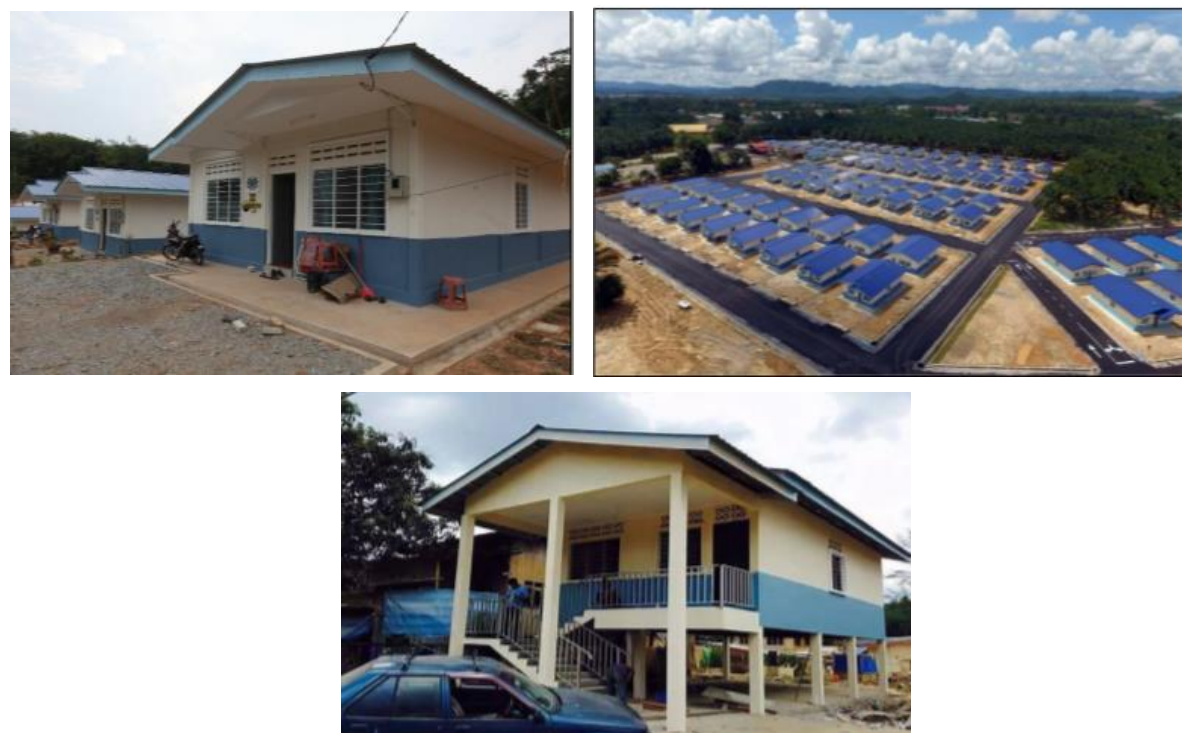

Figure 2: New permanent houses (RKB) in Kuala Krai, Kelantan

\section{RESULTS AND FINDINGS}

\section{Satisfaction on Redevelopment}

In general, none of the respondents was unsatisfied with the redevelopment of their area after the massive flood in the year 2014 (Table 2). Two-third of them felt satisfied or very satisfied with the redevelopment of their area with the RKB. For the aspect of house quality, there was a high percentage of respondents felt satisfied or very satisfied, which was $74 \%$ (Table 3). However, there were $44 \%$ of respondents moderately satisfied with the size of their new houses (Table 4). Only $56 \%$ of them were really satisfied or very satisfied with the size of the house. That means the size of houses is not really adequate for a large proportion of respondents.

Table 2: Overall satisfaction of the redevelopment

\begin{tabular}{lcc}
\hline & Number of respondents & $\%$ \\
\hline Very unsatisfied & 0 & 0 \\
Unsatisfied & 0 & 0 \\
Moderate & 16 & 32 \\
Satisfied & 15 & 30 \\
Very satisfied & 19 & 38 \\
\hline Total & 50 & 100 \\
\hline
\end{tabular}


PLANNING MALAYSIA

Journal of the Malaysia Institute of Planners (2018)

Table 3: Satisfaction with quality of the house

\begin{tabular}{lcc}
\hline & Number of respondents & $\%$ \\
\hline Very unsatisfied & 0 & 0 \\
Unsatisfied & 0 & 0 \\
Moderate & 13 & 26 \\
Satisfied & 27 & 54 \\
Very satisfied & 10 & 20 \\
\hline Total & 50 & 100 \\
\hline
\end{tabular}

Table 4: Satisfaction of size of house

\begin{tabular}{lcc}
\hline & Number of respondents & $\%$ \\
\hline Very unsatisfied & 0 & 0 \\
Unsatisfied & 0 & 0 \\
Moderate & 22 & 44 \\
Satisfied & 21 & 42 \\
Very satisfied & 7 & 14 \\
\hline Total & 50 & 100 \\
\hline
\end{tabular}

For the aspects of security and comfort of their new houses, the majority of them were only moderately satisfied (Table 5 and 6 ). Respondents who were satisfied or very satisfied made up only $24 \%$. There were $6 \%$ of respondents were unsatisfied with the level of comfort of their new redeveloped housing (Table 6). For the aspect of health, half of the respondents felt satisfied or very satisfied (Table 7). Another $50 \%$ of respondents felt moderately satisfied on the health aspect of the house.

Table 5: Satisfaction of security

\begin{tabular}{lcc}
\hline & Number of respondents & $\%$ \\
\hline Very unsatisfied & 0 & 0 \\
Unsatisfied & 0 & 0 \\
Moderate & 38 & 76 \\
Satisfied & 12 & 24 \\
Very satisfied & 0 & 0 \\
\hline Total & 50 & 100 \\
\hline
\end{tabular}

Table 6: Satisfaction of the comfort level

\begin{tabular}{lcc}
\hline & Number of respondents & $\%$ \\
\hline Very unsatisfied & 0 & 0 \\
Unsatisfied & 3 & 6 \\
Moderate & 35 & 70 \\
Satisfied & 10 & 20 \\
Very satisfied & 2 & 4 \\
\hline Total & 50 & 100 \\
\hline
\end{tabular}


Oliver Ling Hoon Leh, Muhammad Shamsul Azdhar Zulkapli, Kwong Qi Jie, \& Nurul Ashikin Mabahwi

Satisfaction of Residents on The Redevelopment of Natural Disaster Area. Case Study: Kuala Krai, Kelantan, Malaysia

Table 7: Satisfaction of the health aspect

\begin{tabular}{lcc}
\hline & Number of respondents & $\%$ \\
\hline Very unsatisfied & 0 & 0 \\
Unsatisfied & 0 & 0 \\
Moderate & 25 & 50 \\
Satisfied & 19 & 38 \\
Very satisfied & 6 & 12 \\
\hline Total & 50 & 100 \\
\hline
\end{tabular}

For the aspects of utility/facilities for the redevelopment area (Table 8 to 12 ), a few respondents expressed their dissatisfaction towards the water supply $(8 \%)$, solid waste management (30\%), the road condition (12\%) and accessibility $(18 \%)$. Most of them were only moderately satisfied with the infrastructure/ facilities provided in the redevelopment area except electricity supply. The water supply of the area was provided by Air Kelantan Sendirian Berhad (AKSB). Sometimes, the water supply in the study area was disconnected due to technical problems. Quality of solid waste management, road condition and accessibility aspects were requiring further improvement after the damages due to the massive flood. For the aspect of electricity, none of them felt unsatisfied with the electricity supply (Table 9), and most of them (96\%) were satisfied.

Table 8: Satisfaction on water supply

\begin{tabular}{lcc}
\hline & Number of respondents & $\%$ \\
\hline Very unsatisfied & 0 & 0 \\
Unsatisfied & 4 & 8 \\
Moderate & 16 & 32 \\
Satisfied & 27 & 54 \\
Very satisfied & 3 & 6 \\
\hline Total & 50 & 100 \\
\hline
\end{tabular}

Table 9: Satisfaction on electricity supply

\begin{tabular}{lcc}
\hline & Number of respondents & $\%$ \\
\hline Very unsatisfied & 0 & 0 \\
Unsatisfied & 0 & 0 \\
Moderate & 2 & 4 \\
Satisfied & 48 & 96 \\
Very satisfied & 0 & 0 \\
\hline Total & 50 & 100 \\
\hline
\end{tabular}

Table 10: Satisfaction on solid waste management

\begin{tabular}{lcc}
\hline & Number of respondents & $\%$ \\
\hline Very unsatisfied & 0 & 0 \\
Unsatisfied & 15 & 30 \\
Moderate & 30 & 60 \\
Satisfied & 5 & 10 \\
Very satisfied & 0 & 0 \\
\hline Total & 50 & 100 \\
\hline
\end{tabular}


PLANNING MALAYSIA

Journal of the Malaysia Institute of Planners (2018)

Table 11: Satisfaction on road condition

\begin{tabular}{lcc}
\hline & Number of respondents & $\%$ \\
\hline Very unsatisfied & 0 & 0 \\
Unsatisfied & 6 & 12 \\
Moderate & 25 & 50 \\
Satisfied & 19 & 38 \\
Very satisfied & 0 & 0 \\
\hline Total & 50 & 100 \\
\hline
\end{tabular}

Table 12: Satisfaction on accessibility

\begin{tabular}{lcc}
\hline & Number of respondents & $\%$ \\
\hline Very unsatisfied & 0 & 0 \\
Unsatisfied & 9 & 18 \\
Moderate & 28 & 56 \\
Satisfied & 13 & 26 \\
Very satisfied & 0 & 0 \\
\hline Total & 50 & 100 \\
\hline
\end{tabular}

\section{Satisfaction of Location and Land Ownership}

The overall satisfaction level of respondents was different among the seven locations of the redevelopment areas in Kuala Krai (Table 13). Data show that all respondents from Kuala Krai Town and Telekong Village were generally satisfied or very satisfied with the redevelopment of their areas and their houses. However, all respondents from Tualang Village were only moderately satisfied with the redevelopment. In other areas, most of the respondents were satisfied or very satisfied with the redevelopment, with some percentage of respondents were moderately satisfied (Table 13). The association between the overall satisfaction level and location was analysed using Chi-square with the $p$ value of 0.097 . It shows that locational factor does affect the overall satisfaction level of respondents on the redevelopment of their areas and their houses.

Table 13: Overall satisfaction by location

\begin{tabular}{lcccc}
\hline & $\begin{array}{c}\text { Moderate } \\
(\%)\end{array}$ & Satisfied $(\%)$ & $\begin{array}{c}\text { Very satisfied } \\
(\%)\end{array}$ & $\begin{array}{c}\text { Total } \\
(\%)\end{array}$ \\
\hline Manek Urai & 42 & 25 & 33 & 100 \\
Sungai Durian & 22 & 28 & 50 & 100 \\
Kampung Pahi & 33 & 33 & 33 & 100 \\
Tualang Village & 100 & 0 & 0 & 100 \\
Karangan Village & 33 & 17 & 50 & 100 \\
Telekong Village & 0 & 100 & 0 & 100 \\
Kuala Krai Town & 0 & 60 & 40 & 100
\end{tabular}

Note: Chi-square test showed an association between location and satisfaction with $\mathrm{p}=0.097$

No respondents for "very unsatisfied" and "unsatisfied"

For the aspect of health, the association with location was significant at 0.05 level. In most of the areas, most of the respondents only felt moderately 
Oliver Ling Hoon Leh, Muhammad Shamsul Azdhar Zulkapli, Kwong Qi Jie, \& Nurul Ashikin Mabahwi

Satisfaction of Residents on The Redevelopment of Natural Disaster Area. Case Study: Kuala Krai, Kelantan, Malaysia

satisfied with the health aspect of their redeveloped houses (Table 14). However, all of the respondents in Tualang Village were satisfied with their new houses. Meanwhile, the majority of the respondents in Sungai Durian were satisfied with their new houses. It showed that factor of location also affects the satisfaction level on the aspect of health.

Table 14: Satisfaction on health aspect by location

\begin{tabular}{lcccc}
\hline & $\begin{array}{c}\text { Moderate } \\
(\%)\end{array}$ & Satisfied $(\%)$ & $\begin{array}{c}\text { Very satisfied } \\
(\%)\end{array}$ & $\begin{array}{c}\text { Total } \\
(\%)\end{array}$ \\
\hline Manek Urai & 83 & 17 & 0 & 100 \\
Sungai Durian & 28 & 56 & 17 & 100 \\
Kampung Pahi & 100 & 0 & 0 & 100 \\
Tualang Village & 0 & 100 & 0 & 100 \\
Karangan Village & 50 & 17 & 33 & 100 \\
Telekong Village & 50 & 50 & 0 & 100 \\
Kuala Krai Town & 60 & 20 & 20 & 100
\end{tabular}

Note: Chi-square test showed a significant association between location and satisfaction on healthy aspect at 0.05 level $(\mathrm{p}=0.030)$

No respondents for "very unsatisfied" and "unsatisfied".

For the redevelopment of the study area, the new houses were constructed on either individual land or government land. The land ownership also affects the level of satisfaction among respondents. However, the association between ownership and overall satisfaction was not significant even at 0.05 level (Table 15). Most of the respondents who were staying at their own new houses or on the government land were satisfied or very satisfied (> 60\% for self-owned, $>75 \%$ for government land). There were $50 \%$ of the respondents who were staying on family land. They were only moderately satisfied with the newly redeveloped houses (Table 15).

Table 15: Overall satisfaction by land ownership

\begin{tabular}{lcccc}
\hline \multicolumn{1}{c}{ Ownership } & $\begin{array}{c}\text { Moderate } \\
(\%)\end{array}$ & Satisfied $(\%)$ & $\begin{array}{c}\text { Very satisfied } \\
(\%)\end{array}$ & $\begin{array}{c}\text { Total } \\
(\%)\end{array}$ \\
\hline Self & 36 & 32 & 32 & 100 \\
Family & 50 & 25 & 25 & 100 \\
Government & 22 & 28 & 50 & 100 \\
\hline Note: Chi-square test showed a not significant association between overall satisfaction and ownership even at \\
0.05 level. \\
No respondents for "very unsatisfied" and "unsatisfied".
\end{tabular}

The association between satisfaction on the health aspect of their new houses and land ownership was showing significant association at 0.05 level $(p=0.043)$. It showed a significant effect of land ownership on health satisfaction of respondents of their newly redeveloped houses. Majority of the respondents on family land and government land were satisfied or very satisfied with the health aspect of their new houses 
(Table 16). However, the majority of the respondents (68\%) who were staying on their own land were only moderately satisfied with the health aspect of their new houses.

Table 16: Satisfaction on the heath aspect by land ownership

\begin{tabular}{lcccc}
\hline \multicolumn{1}{c}{ Ownership } & $\begin{array}{c}\text { Moderate } \\
(\%)\end{array}$ & Satisfied (\%) & $\begin{array}{c}\text { Very satisfied } \\
(\%)\end{array}$ & $\begin{array}{c}\text { Total } \\
(\%)\end{array}$ \\
\hline Self & 68 & 21 & 11 & 100 \\
Family & 25 & 75 & 0 & 100 \\
Government & 28 & 56 & 17 & 100 \\
\hline
\end{tabular}

Note: Chi-square test showed a not significant association between overall satisfaction and ownership even at 0.05 level $(\mathrm{p}=0.043)$

No respondents for "very unsatisfied" and "unsatisfied"

\section{SUMMARY AND CONCLUDING REMARKS}

It was found that majority of the respondents were satisfied with their newly redeveloped houses and the infrastructure. A small percentage of respondents expressed their dissatisfaction on the aspects of comfort, water supply, solid waste management, road condition and accessibility. The satisfaction level was mostly associated with the locational and land ownership factors. The level of satisfaction differs according to the areas and type of land.

\section{ACKNOWLEDGEMENT}

The authors would like to thank Universiti Teknologi MARA (UiTM) for the support and partly funding the study through the BESTARI grant (600IRMI/MYRA 5/3/BESTARI (008/2017)). The authors would also like to thank all the departments, organisations and individuals who had contributed to this study.

\section{REFERENCES}

Bernama (2014, December 21). Mengimbau kembali bencana tsunami 2004. Retrieved from http://www.astroawani.com/berita-malaysia/mengimbau-kembalibencana-tsunami-2004-32061

Carrasco, S., Ochiai, C., \& Okazaki, K. (2017). Residential satisfaction and housing modifications: A study in disaster-induced resettlement sites in Cagayen de Oro, Philipines. International Journal of Disaster Resilience in the Built Environment, 8(2), 175-189.

Danquah, J. A., Attippoe A, J., \& Ankrah, J. S. (2014). Assessment of residential satisfaction in the resettlement towns of the Keta Basin in Ghana. International Journal Civil Engineering, Construction and Estate Management, 2(3), 26-45.

Jasbindar, F. A. (2017, July 20). Tragedi Pos Dipang, bencana banjir lumpur di Kampar tahun 1996. Retrieved from https://www.orangperak.com/tragedi-pos-dipangbencana-banjir-lumpur-di-kampar-tahun-1996.html

Mengingati Tsunami 2004 (2014, December 21). Retrieved from http://www.utusan.com.my/berita/luar-negara/mengingati-tsunami-20041.39240 
Oliver Ling Hoon Leh, Muhammad Shamsul Azdhar Zulkapli, Kwong Qi Jie, \& Nurul Ashikin Mabahwi

Satisfaction of Residents on The Redevelopment of Natural Disaster Area. Case Study: Kuala Krai, Kelantan, Malaysia

National Security Council (2014). National Security Council Directive No. 20 - Policy and mechanism of national disaster management and relief. Malaysia: Prime Minister's Department.

Rani, W. N. M. W. M., Nifa, F. A., Ismail, M. N., \& Khalid, K. N. (2017). Planning for post disaster recovery: Lesson learnt from flood events in Kelantan Malaysia. AIP Conference Proceedings 1891, 020143. (n.p.): American Institute of Physics.

Wijegunarathna, E., Wedawatta, G., Prasanna, L., \& Ingirige, B. (2018). Long-term satisfaction of resettled communities: An assessment of physical performance of post-disaster housing. Procedia Engineering, 212, 1147-1154. 